\title{
Purification of Glutathione Reductase from Human Erythrocytes: Inhibition Profile of Some Anti-Epileptic Drugs
}

\section{Yeliz DEMİR ${ }^{1 *}$}

\begin{abstract}
Glutathione reductase (GR) is found in the NADPH-dependent oxidoreductase family. GR has various important functions in the cell, such as protein and DNA biosynthesis, the detoxification of reactive oxygen species and free radicals. The purpose of this research was to perform the in vitro inhibition effects of anti-epileptic drugs (phenytoin, gabapentin, and primidone) on GR enzyme. In the current study, the GR enzyme was purified from human erythrocytes with a specific activity of 20.08 EU/mg protein and 2135.97-purification fold. To determine the inhibition effects of anti-epileptic drugs on GR enzyme, Lineweaver-Burk graphs were drawn for each inhibitor. $\mathrm{K}_{\mathrm{i}}$ values and inhibition types were determined from these plotted graphs. The $\mathrm{K}_{\mathrm{i}}$ values of drugs were found in ranging from $0.15 \pm$ 0.03-5.74 $\pm 1.14 \mathrm{mM}$. Phenytoin was shown the most effective inhibitor feature with a competitive inhibition type.
\end{abstract}

Keywords: anti-epileptic drugs, enzyme inhibition, enzyme purification, glutathione reductase

\section{Glutatyon Redüktaz Enziminin İnsan Eritrositlerinden Saflaştırılması: Bazı Anti-epileptik ilaçların İnhibisyon Profili}

ÖZET: Glutatyon redüktaz (GR), NADPH'ye bağlı oksidoredüktaz ailesinde bulunur. GR hücrede protein ve DNA biyosentezi, reaktif oksijen türlerinin ve serbest radikallerin detoksifikasyonu gibi çeşitli önemli fonksiyonlara sahiptir. Bu çalışmanın amacı, GR enzimi üzerine antiepileptik ilaçların (fenintoin, gabapentin ve pirimidon) in vitro etkilerini belirlemektir. Bu çalışmada, GR enzimi insan eritrositlerinden $20.08 \mathrm{EU} / \mathrm{mg}$ protein spesifik aktivite ve 2135.97 kat saflaştırıldı. Anti-epileptik ilaçların GR enzimi üzerindeki inhibisyon etkisini belirlemek için Lineweaver-Burk grafikleri çizildi;

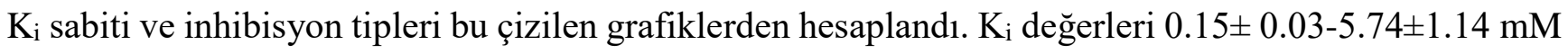
aralığında bulundu. Fenintoin en etkili inhibitör özelliğini yarışmalı inhibisyon tipi ile göstermiştir.

Anahtar Kelimeler: Anti-epileptik ilaçlar, enzim inhibisyonu, enzim saflaştırılması, glutatyon redüktaz

${ }^{1}$ Yeliz DEMIR (Orcid ID: 0000-0003-3216-1098), Department of Pharmacy Services, Nihat Delibalta Göle Vocational High School, Ardahan University, Ardahan, Turkey

*Sorumlu Yazar / Corresponding Author: Yeliz DEMIR, E- mail: yelizdemir2116@gmail.com 


\section{INTRODUCTION}

Free radicals are carried many electrons at molecular orbitals. Free radicals such as alkoxyl, hydroxyl, superoxide, peroxyl, nitrogen dioxide, and nitric oxide are derived from oxygen (Ozaslan et al., 2017) These compounds are formed in organisms by the external effects or via metabolic ways and bind irreversibly to DNA and proteins (Ozaslan et al., 2018). They also cause degradation of structural coenzymes, nucleotide, and DNA in tissues and cells (Ceylan et al., 2019; Demir and Köksal, 2019). Also, they can bind covalently to enzymes, proteins, and lipids; break down cell membranes; damage transport systems; change enzyme activities; and cause metabolic diseases (Demir et al., 2017a; 2018a).

Epilepsy is a serious, chronic, and prevalent neurologic disease. Epilepsy treatment requires antiepileptic drugs (Beydemir and Demir 2016). Phenytoin is employed as an anti-arrhythmic and anti-convulsant drug. It is effective for the prevalent forms of epileptic seizures (Farber et al. 2002). Primidone is an anticonvulsant drug. It is used generally in the treatment of psychiatric problem and bipolar disorder (Yamatogi et al., 2004). Gabapentin is a useful to prevent repeated migraine headaches, neuropathic pain, treatment of neuropathic pain in diabetic neuropathy, and nystagmus (Heli et al., 2012).

It is well known that enzymes are crucial bio-catalyzers in the metabolism. Therefore, all substances taken in the body may interact with various enzymes. Especially some enzymes are called drug-target and chemical target (Caglayan et al., 2018; Parham et al., 2018a). Glutathione reductase (GR) is found in the NADPHdependent oxidoreductase family. The enzyme catalyzes the reduction of glutathione disulfide to the sulfhydryl form glutathione. GR has various important functions of the cell, such as protein and DNA biosynthesis, the detoxification of reactive oxygen species and free radicals (Budak et al., 2014).

In the present study, it was evaluated the impacts of antiepileptic drugs such as phenytoin, gabapentin, and primidone (Figure 1) on human GR enzyme activity.

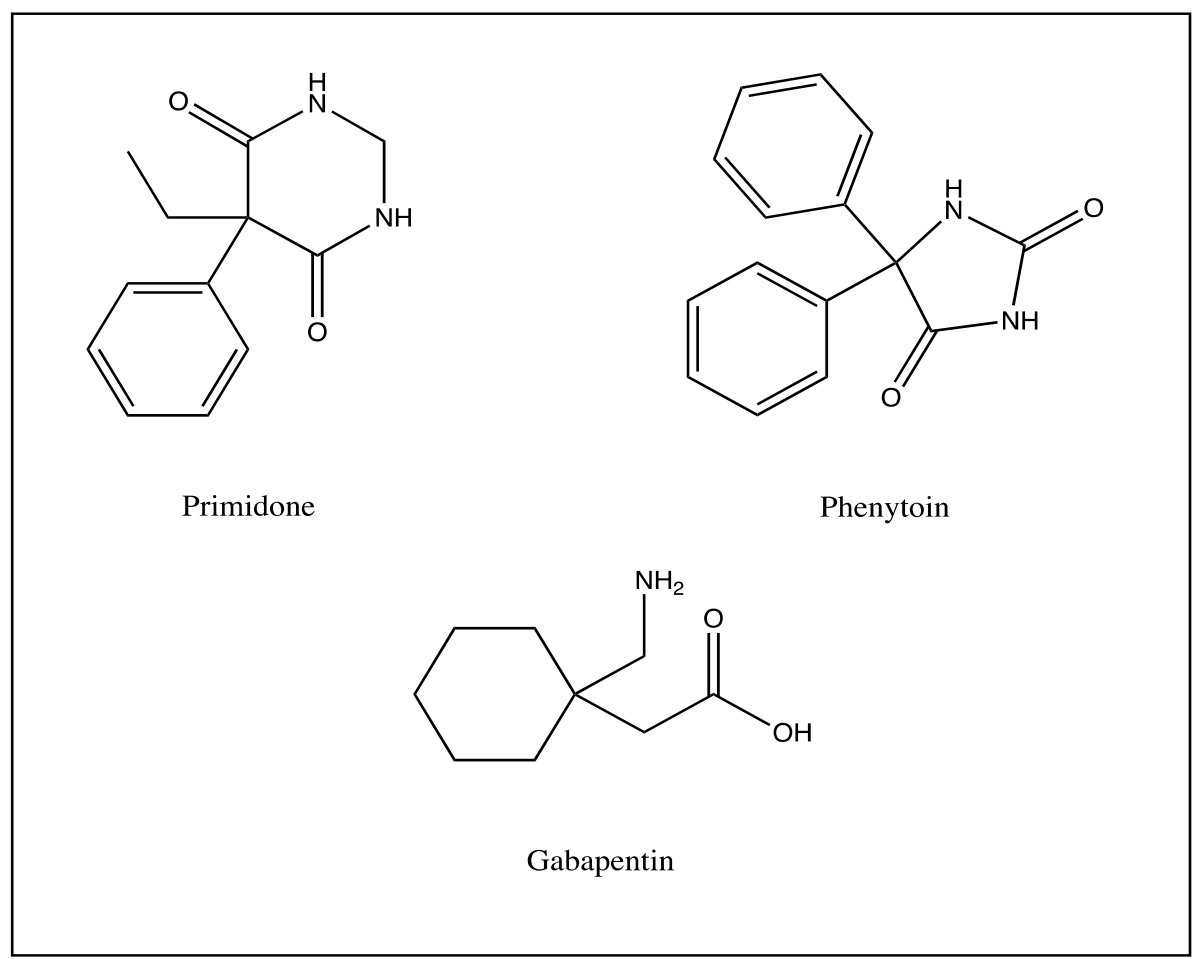

Figure 1. The molecular structure of anti-epileptic drugs used in this study. 


\section{MATERIAL AND METHOD}

\section{Chemicals}

All chemicals were obtained from Sigma Chemical Co. Standard protein markers for electrophoresis were obtained from Thermo Fisher Scientific Company.

\section{Human Erythrocytes Hemolysate Preparation}

Fresh blood samples taken into the tubes including EDTA were centrifugated at $1500 \mathrm{xg}$ for $15 \mathrm{~min}$. Thus, three phases were obtained as leukocyte, plasma, and erythrocytes. Plasma and leukocyte phases were removed. The erythrocytes were taken, and they were washed with $0.9 \%$ $\mathrm{NaCl}$ solution three times. Subsequently, pure erythrocytes were shaken by adding $5 \mathrm{x}$ ice water throughout 30 minutes. To remove the impurities, the hemolysate was centrifuged at $15.000 \mathrm{xg}$ for $30 \mathrm{~min}$, and the supernatant was used for the purification process and activity of the enzyme (Aslan et al., 2018; Turkan et al., 2019).

\section{Activity assay}

GR activity was performed by the method of Carlberg and Mannervik (1985).

\section{Purification of GR}

Human erythrocytes hemolysate applied to 2'5'-ADP Sepharose-4B affinity column equilibrated with $0.1 \mathrm{M} \mathrm{K}$-phosphate buffer +0.1 M K-acetate ( $\mathrm{pH}$ 6.0). The column was washed with $30 \mathrm{ml}$ of $0.1 \mathrm{M} \mathrm{K}$-phosphate buffer $+0.1 \mathrm{M}$ K-acetate ( $\mathrm{pH} 6.0)$, and $30 \mathrm{ml}$ of $0.1 \mathrm{M} \mathrm{K}$ phosphate buffer+ $0.1 \mathrm{M} \mathrm{K}$-acetate $(\mathrm{pH} 7.8)$. Additional washing was carried out $50 \mathrm{mM} \mathrm{K}$ phosphate buffer including $1 \mathrm{mM}$ EDTA, pH 7.0. Elutions were collected in $1 \mathrm{~mL}$ aliquots, and enzyme activity was performed at $340 \mathrm{~nm}$ (Şentürk et al., 2008).

\section{Protein quantity assay}

Quantitative amounts of GR enzyme were determined according to the Bradford (1976) procedure at $595 \mathrm{~nm}$, spectrophotometrically.

\section{SDS-polyacrylamide gel electrophoresis}

According to Laemmli's procedure (1970), the presence and purity of GR were observed by the SDS-PAGE technique. The method was performed according to our previous studies (Demir and Beydemir 2015; Demir et al., 2017b; 2018b).

\section{In vitro inhibition studies}

The inhibition effects of epilepsy drugs were investigated at least five different inhibitor concentrations on GR enzyme. The $\mathrm{K}_{\mathrm{i}}$ values and inhibition types were found by Lineweaver and Burk's curves (1934).

\section{RESULTS AND DISCUSSION}

Oxidative stress occurs overproduction of free radicals and oxidants cause the homeostasis in the body and afterward leading to serious imbalance. It arises from different sources of lifestyle or disease state such as chronic hyperglycemia or episodes of ketosis, excessive nutrient intake, and sleep restriction (Türkeş et al., 2019). The imbalance between antioxidants and oxidants impair the lipids, DNA, and proteins which in turn bring about cell death and physiological dysfunction of the cells. Oxidative stress is thought as the most important contributor in the cardiovascular disease, a neurodegenerative disease like Alzheimer and epilepsy (Is1k et al., 2015; Demir et al., 2016; Taslimi et al., 2018b).

Enzymatic defense is supplied by a number of enzyme systems such as DNA repair enzymes glutathione reductase, glutathione S-transferase, aldo-ketoreductase, catalase, glutathione peroxidase, and superoxide dismutase(Alım et al., 2019). In the presence of NADPH, GR catalyzes the reduction of oxidized glutathione. Reduced glutathione is used in the protection of the thiol groups of intracellular proteins, detoxification of xenobiotics, counteraction of oxidative events, and scavenging of $\mathrm{H}_{2} \mathrm{O}_{2}$ and other organic peroxides (Erat et al., 2005). 
Metabolic processes in living organisms are closely related to the catalytic activity of enzymes. Changes in enzyme activity can cause various diseases. Thus, compounds which inhibit enzyme activity must be beneficial therapeutic agents (Kır1c1 et al., 2016). Hence, it was focused on the in vitro inhibition role of some epilepsy drugs (phenytoin, gabapentin, and primidone) on GR enzyme activity in the present study. For this purpose, GR was purified from human erythrocytes using the simple chromatic method. The GR enzyme was purified with a specific activity of $20.08 \mathrm{EU} / \mathrm{mg}$ protein and 2135.97- purification fold. (Table 1). SDS-PAGE is generally used determination of molecular weight of enzyme. After purification by affinity chromatography, the enzyme eluate was electrophoretically analyzed by SDS PAGE. According to PAGE results, the molecular weight of GR from human erythrocytes was near approximately $51 \mathrm{kDa}$ (Figure 2).

$\mathrm{IC}_{50}$ values of phenytoin, gabapentin, and primidone were found 1.72, 2.06 and $3.09 \mathrm{mM}$ respectively (Figure 3).

Table 1. Summary of the GR purification procedure from human erythrocytes

\begin{tabular}{lcccccc}
\hline Purification Steps & $\begin{array}{c}\text { Total volume } \\
(\mathbf{m L})\end{array}$ & $\begin{array}{c}\text { Total protein } \\
(\mathbf{m g})\end{array}$ & $\begin{array}{c}\text { Total activity Specific activity } \\
(\mathbf{E U})\end{array}$ & $\begin{array}{c}\text { Purification } \\
\text { (EU/mg) }\end{array}$ & $\begin{array}{c}\text { Yield } \\
(\boldsymbol{\%})\end{array}$ \\
\hline Hemolysate & 20 & 605.00 & 5.70 & $9.4 \times 10^{-3}$ & 1 & 100 \\
& & & & & & \\
2'-5' ADP- Sepharose 4B & 4 & 0.128 & 2.57 & 20.08 & 2135.97 & 45.09 \\
Affinity Chromatography & & & & &
\end{tabular}

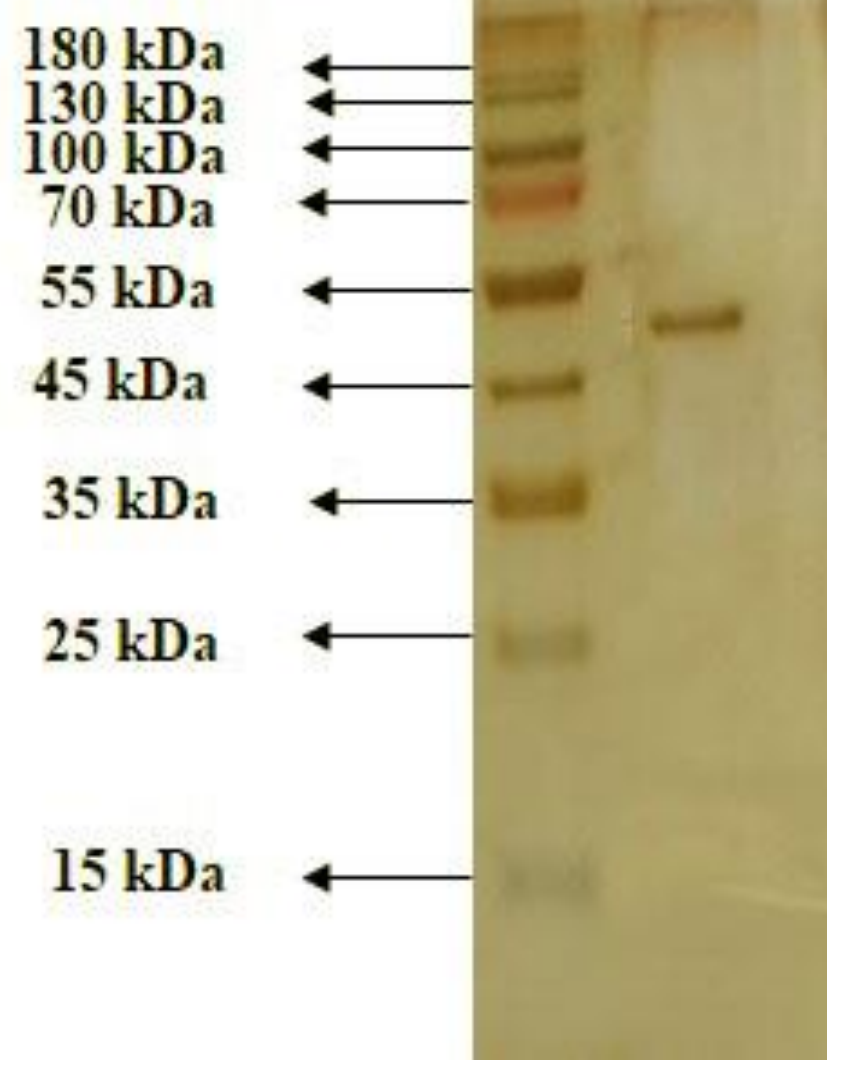

Figure 2. Sodium dodecyl sulfate-polyacrylamide gel electrophoresis for GR enzyme 

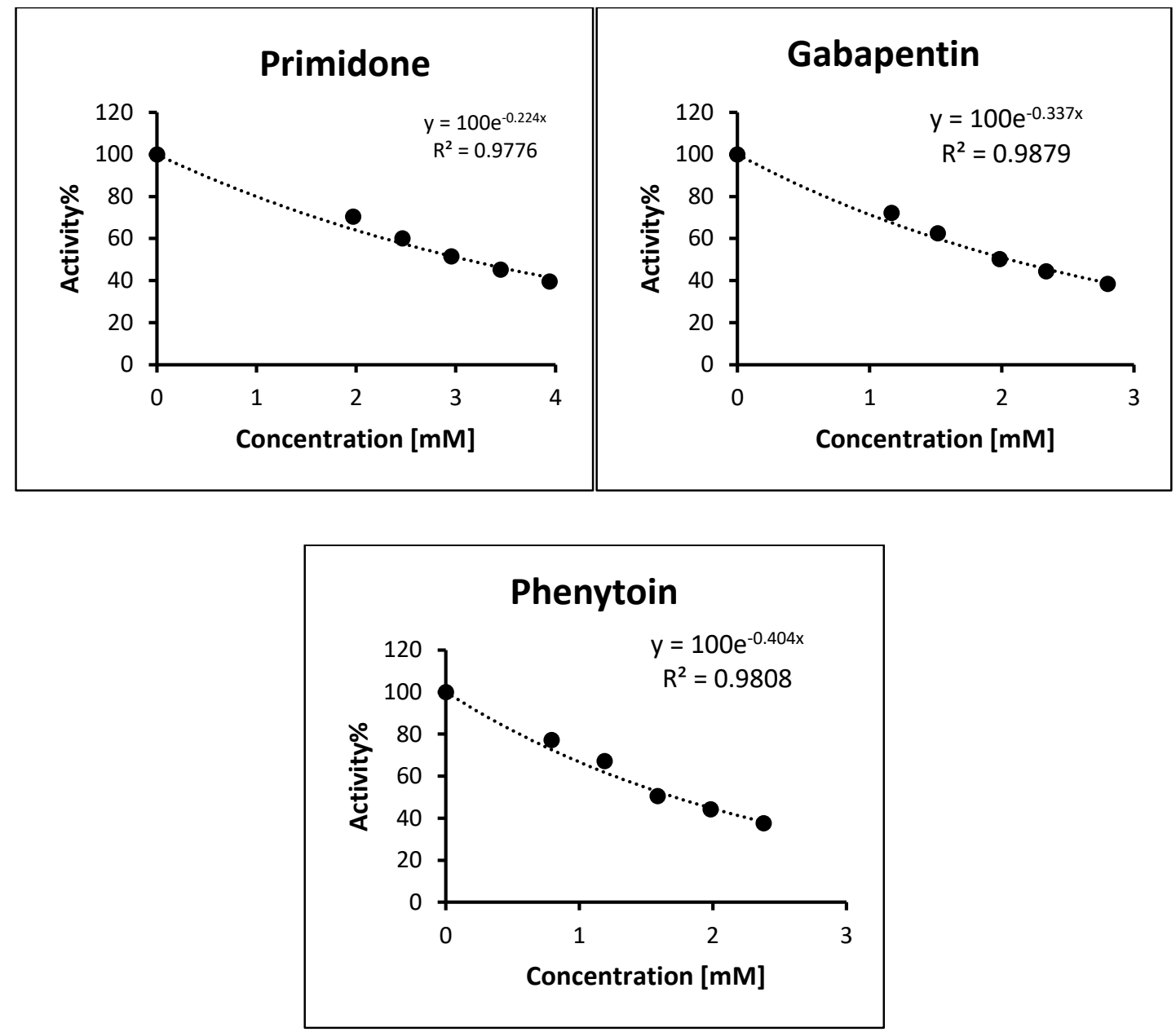

Figure 3. The half maximal inhibitory concentration values $\left(\mathrm{IC}_{50}\right)$ of drugs for $\mathrm{GR}$

This study showed that $\mathrm{K}_{\mathrm{i}}$ values order of compounds showing inhibitory potency was phenytoin $(0.15 \pm 0.03 \mathrm{mM})>$ gabapentin $(0.19 \pm 0.05 \mathrm{mM})>$ primidone $(5.74 \pm 1.14 \mathrm{mM})$ against purified GR. It is reported that these drugs, which show potential inhibitor properties for GR, reduced the enzyme activity at low concentrations (Table 2).

Table 2. $\mathrm{IC}_{50}, \mathrm{~K}_{\mathrm{i}}$ values and inhibition types of epilepsy drugs on GR

\begin{tabular}{cccl}
\hline Epilepsy Drugs & IC50 $(\mathbf{m M})$ & $\mathbf{K}_{\mathbf{i}}(\mathbf{m M})$ & Inhibition type \\
\hline Phenytoin & 1.72 & $0.15 \pm 0.03$ & Competitive \\
Gabapentin & 2.06 & $0.19 \pm 0.05$ & Competitive \\
Primidone & 3.09 & $5.74 \pm 1.14$ & Noncompetitive \\
\hline
\end{tabular}

According to our results, phenytoin showed a stronger inhibitory effect against GR while primidone showed the lowest inhibitory effect. It was found that phenytoin and gabapentin showed competitive inhibition effect, primidone showed non-competitive inhibition. It may have an interaction with the amino acids of the active site (Figure 4). 

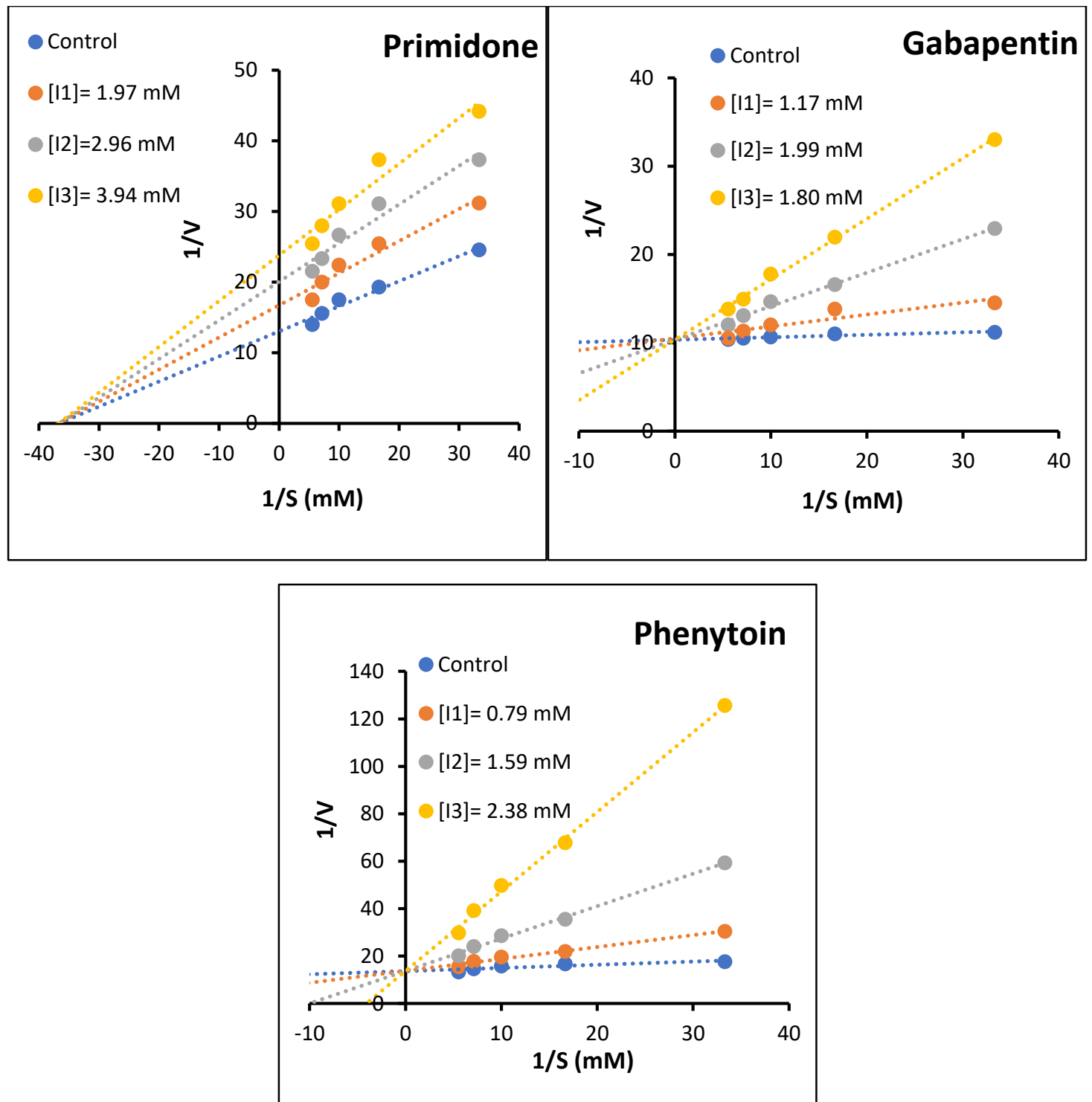

Figure 4. Determination of Lineweaver-Burk graphs for drugs on GR

Some reports are found on GR inhibition by drugs, and various chemicals. For instance, Şentürk et al., (2008) investigated the inhibition of some antibiotics on purified human erythrocyte GR. They found that sulfanylacetamide, rifamycin imipenem, ceftazidime, ceftriaxone, chloramphenicol, vancomycin, ornidazole, and cefuroxime showed inhibitory effects, but lincomycin, amikacin clindamycin, and amoxicillin showed activatory effects on the enzyme. According to this study, imipenem was showed the best inhibition effect. In another study, the inhibition of methotrexate, dacarbazine, pantoprazole sodium, 5-fluorouracil thiocolchicoside, and olanzapine was found on GR. The enzyme is mostly inhibited by dacarbazine (Akkemik et al., 2011). Researchers studied that the impacts of Schiff base derivatives on baker's yeast GR. These compounds were displayed as effective inhibition profiles (Balaydın et al., 2018).

\section{CONCLUSION}

In conclusion that GR enzyme was purified from human erythrocytes. After then, in vitro inhibition studies of anti-epileptic drugs were performed on this enzyme activity. It can be considered that epilepsy drugs may be effective on GR. The findings from this study make several contributions to the literature. However, further biological studies such as gene expression and in vivo experiment should be done for these drugs. 


\section{REFERENCES}

Akkemik E, Şenturk M, Özgeriş FB, Taşer, P, Çiftci $\mathrm{M}, 2011$. In vitro effects of some drugs on human erythrocyte glutathione reductase. Turkish Journal of Medical Sciences, 41(2): 235-241.

Alım Z, Kilıc D, Demir Y, 2018. Some indazoles reduced the activity of human serum paraoxonase 1, an antioxidant enzyme: in vitro inhibition and molecular modeling studies. Archives of Physiology and Biochemistry, 125(5):387-395

Aslan HE, Demir Y, Ozaslan MS, Türkan F, Beydemir S, Kufrevioglu OI, 2018. The behavior of some chalcones on acetylcholinesterase and carbonic anhydrase activity. Drug and Chemical Toxicolology, 42(6):634-640.

Balaydın HT, Özil M, Şentürk M, 2018. Synthesis and glutathione reductase inhibitory properties of 5methyl-2,4-dihydro-3H-1,2,4-triazol-3-one's aryl Schiff base derivatives. Archiv der Pharmazie, e1800086.

Beydemir S, Demir Y, 2017. Antiepileptic drugs: impacts on human serum paraoxonase-1. Journal of Biochemical and Molecular Toxicology, 31(6): e21889.

Bradford MM, 1976. A rapid and sensitive method for the quantitation of microgram quantities of protein utilizing the principle of protein-dye binding. Analytical Biochemistry, 72: 248-254.

Budak H, Kocpinar EF, Gonul N, Ceylan H, Erol HS, Erdogan O, 2014. Stimulation of gene expression and activity of antioxidant-related enzyme in Sprague Dawley rat kidney induced by long-term iron toxicity. Comparative Biochemistry and Physiology - Part C, 166: 4450.

Caglayan C, Demir Y, Kücükler S, Taslimi P, Kandemir FM, Gulcin, I, 2018. The Effects of Hesperidin on Sodium Arsenite-Induced Different Organ Toxicity in Rats on Metabolic Enzymes as Antidiabetic and Anticholinergics Potentials: A Biochemical Approach. Journal of Food Biochemistry, 43(2): e12720.

Carlberg I, Mannervik B, 1985. Methods Enzymol Academic Press, Orlando FL.
Ceylan H, Demir Y, Beydemir, Ş, 2019. Inhibitory effects of usnic and carnosic acid on some metabolic enzymes: an in vitro study. Protein Peptide Letters, 26(5):364-370.

Demir Y, Beydemir S, 2015. Purification, refolding, and characterization of recombinant human paraoxonase-1. Turkish Journal of Chemistry, 39: 764-776.

Demir Y, Dikbaş N, Beydemir Ş, 2018b. Purification and Biochemical Characterization of Phytase Enzyme from Lactobacillus coryniformis (MH121153) Molecular Biotechnology, 60(11): 783-790.

Demir Y, Isık M, Gulcin I, Beydemir S, 2017a. Phenolic compounds inhibit the aldose reductase enzyme from the sheep kidney. Journal of Biochemical and Molecular Toxicology, 31(9): e21935.

Demir Y, Kotan M, Dikbaş N, Beydemir Ş, 2017b. Phytase from Weissella halotolerans: Purification, partial characterization and the effect of some metals. International Journal of Food Properties, 20(2): 2127-2137.

Demir Y, Köksal, Z, 2019. The inhibition Effects of Some Sulfonamides on Human Serum Paraoxonase-1 (hPON1), Pharmacological Reports, 71(3):545-549.

Demir Y, Oruç E, Topal A, 2016. Carbonic Anhydrase Activity Responses and Histopathological Changes in Gill and Liver Tissues after Acute Exposure to Chromium in Brown Trout Juveniles. Hacettepe Journal of Biology and Chemistry, 44 (4): 515-523.

Demir Y, Taslimi P, Ozaslan MS, Oztaskin N, Çetinkaya Y, Gulçin İ, Beydemir Ş, Goksu S, 2018a. Antidiabetic potential: In vitro inhibition effects of bromophenol and diarylmethanones derivatives on metabolic enzymes. Archiv der Pharmazie, 351(12):e1800263.

Erat M, Sakiroglu H, Ciftci M, 2005. Effects of some antibiotics on glutathione reductase activities from human erythrocytes in vitro and from rat erythrocytes in vivo. Journal of Enzyme Inhibition and Medicinal Chemistry, 20: 69-74. 
Farber NB, Jiang XP, Heinkel C, Nemmers B, 2002. Antiepileptic drugs and agents that inhibit voltage-gated sodium channels prevent NMDA antagonist neurotoxicity. Molecular Psychiatry, 7(7): 726-33.

Heli H, Faramarzi F, Sattarahmady N, 2012. Oxidation and determination of Gabapentin on nanotubes of nickel oxide-modified carbon paste electrode, Journal of Solid State Electrochemistry, 16(1): 45-52.

Işık M, Demir Y, Kırıcı M, Demir R, Şimşek F, Beydemir Ş, 2015. Changes in the anti-oxidant system in adult epilepsy patients receiving antiepileptic drugs. Archives of Physiology and Biochemistry, 121: 97-102.

Kırıc1 M, Kırıcı M, Demir Y, Beydemir Ş, Atamanalp $\mathrm{M}, 2016$. The Effect of $\mathrm{Al}^{3+}$ and $\mathrm{Hg}^{2+}$ on Glucose 6-Phosphate Dehydrogenase from Capoetaumbla kidney. Applied Ecology and Environmental Research, 14(2): 253-264.

Laemmli UK, 1970. Cleavage of structural proteins during the assembly of the head of bacteriophage T4. Nature, 227: 680-685.

Lineweaver H, Burk D, 1934. The determination of enzyme dissociation constants. Journal of the American Chemical Society, 56: 658-666.

Ozaslan MS, Demir Y, Aslan HE, Beydemir S, Kufrevioglu OI, 2018. Evaluation of chalcones as inhibitors of glutathione S-transferase. Journal of Biochemical and Molecular Toxicology, 32(5), e22047.

Ozaslan MS, Demir Y, Kufrevioglu OI, Ciftci M, 2017. Some metals inhibit the Glutathione Stransferase from Van Lake fish gills. Journal of Biochemical and Molecular Toxicology, 31(11): e21967.

Senturk M, Kufrevioglu OI, Ciftci M, 2008. Effects of some antibiotics on human erythrocyte glutathione reductase: an in vitro study. Journal of Enzyme Inhibition and Medicinal Chemistry, 23(1): 144-148.
Taslimi P, Aslan HE, Demir Y, Oztaskin N, Maraş A, Gulçin İ, Beydemir S, Goksu S, 2018b. Diarylmethanon, bromophenol and diarylmethane compounds: Discovery of potent aldose reductase, $\alpha$-amylase and $\alpha$-glycosidase inhibitors as new therapeutic approach in diabetes and functional hyperglycemia. International Journal of Biological Macromolecules, 119: 857-863.

Taslimi P, Kandemir FM, Demir Y, Ileritürk M, Temel Y, Caglayan C, Gulcin, I, 2018a. The Antidiabetic and Anticholinergic Effects of Chrysin on Cyclophosphamide-Induced Multiple Organs Toxicity in Rats: Pharmacological Evaluation of Some Metabolic Enzymes Activities. Journal of Biochemical and Molecular Toxicology, 33(6):e22313.

Türkan F, Huyut Z, Demir Y, Ertaş F, Beydemir Ş, 2018. The effects of some cephalosporins on acetylcholinesterase and glutathione Stransferase: an in vivo and in vitro study. Archives of Physiology and Biochemistry, 125(3):235-243.

Türkeş C, Demir Y, Beydemir S, 2019. Anti-diabetic Properties of Calcium Channel Blockers: Inhibition Effects on Aldose Reductase Enzyme activity. Applied Biochemistry and Biotechnology, 189(1):318-329.

Yamatogi Y, 2004. Principles of antiepileptic drug treatment of epilepsy. Psychiatry and Clinical Neurosciences, 58(3): 3-6. 